\title{
Pure red cell aplasia caused by Parvo B19 virus in a kidney transplant recipient
}

\author{
Baral A 1 , Poudel B ${ }^{2}$, Agrawal RK 1 , Hada R' ${ }^{1}$, Gurung $S^{1}$ \\ 1 Department of Nephrology, National Academy of Medical Sciences, Bir Hospital, Kathmandu \\ ${ }^{2}$ Civil Service Hospital of Nepal, Baneswor, Kathmandu
}

\section{ABSTRACT}

Parvo B19 is a single stranded DNA virus, which typically has affinity for erythroid progenitor cells in the bone marrow and produces a severe form of anemia known as pure red cell aplasia. This condition is particularly worse in immunocompromised individuals. We herein report a young Nepali male who developed severe and persistent anaemia after kidney transplantation while being on immunosuppressive therapy. His bone marrow examination revealed morphological changes of pure red cell aplasia, caused by parvovirus B19. The IgM antibody against the virus was positive and the virus was detected by polymerase chain reaction in the blood. He was managed with intravenous immunoglobulin. He responded well to the treatment and has normal hemoglobin levels three months post treatment. To the best of our knowledge, this is the first such case report from Nepal.

Keywords: Intravenous immunoglobulin, kidney transplant recipient, Parvovirus B19, pure red cell aplasia

\section{INTRODUCTION}

Parvo B19 is a single stranded DNA virus with special affinity for the erythroid progenitor cells of the bone marrow. ${ }^{1}$ In children, Parvovirus B19 infection causes a transient anaemia associated with an erythematous rash called the fifth disease or Erythema infectiosum. Occasionally, in immunocompetent adults, a symmetric polyarthropathy mimicking rheumatoid arthritis occurs. ${ }^{2}$ The special affinity to erythroid progenitors in the bone marrow causes transient aplastic crisis in individuals with an underlying haemolytic anaemia. ${ }^{3}$ It causes destruction of the proerythroblasts producing mild anaemia in immunocompetent people. ${ }^{4}$ and infections are reported from all over the world. ${ }^{5}$

In people who are immunocompromised, for example kidney transplant recipients on continuous immunosuppressive medications, the inability to generate an immune response leads to a state of persistent anaemia, reticulocytopenia caused by lytic destruction of proerythroblasts giving rise to an acquired pure red cell aplasia (PRCA). ${ }^{6}$ The recommended treatment for these patients is intravenous gammaglobulin (IVIG) that replaces neutralizing antibodies which the patient does not possess; however, it is unknown whether the virus is always eliminated completely by this treatment. ${ }^{7}$

\section{CASE REPORT}

A Nepali boy aged 18 years had end stage renal disease due to chronic glomerulonephritis and had received hemodialysis for two months prior getting a kidney transplant from his mother. He received standard induction therapy with two doses of basiliximab (IL 2 receptor blocker) on day $\mathrm{O}$ and day 4 post transplant. $\mathrm{He}$ received a combination immunosuppressive medication consisting of tacrolimus, mycophenolatemofetil and prednisolone.

Correspondence:

Dr. Anil Baral

Deprtment of Nephrology, Bir hospital

National Academy of Medical Sciences, Kathmandu, Nepal

Tel No: 9841292733

E-mail: anilbaral@hotmail.com 
The patient's pre transplant hemoglobin was 12.4 $\mathrm{g} / \mathrm{dL}$ and was receiving erythropoietin 4000 units twice a week. He was discharged from hospital on the $18^{\text {th }}$ post-operative day. His medications at discharge were tacrolimus $4 \mathrm{mg}$ twice daily, mycophenolatemofetil $500 \mathrm{mg}$ twice daily, prednisolone $20 \mathrm{mg}$ once daily, fluconazole $50 \mathrm{mg}$ once daily, Cotrimoxazole + trimethoprim DS $1 / 2$ tab once daily, amlodipine $10 \mathrm{mg}$ once daily, prazosin 10 mg twice daily, aspirin 75 mg daily, oral iron and folic acid supplements and injection erythropoietin 2000 units twice weekly. At discharge his hemoglobin was $7.3 \mathrm{~g} / \mathrm{dL}$ and serum creatinine was $1.7 \mathrm{mg} / \mathrm{dL}$.

On his first post-operative follow up his hemoglobin was $8.5 \mathrm{~g} / \mathrm{dL}$ and serum creatinine was $1.3 \mathrm{mg} / \mathrm{dL}$. His erythropoietin was increased to 4000 units twice weekly and tacrolimus was adjusted according to serum level. By the end of one month his hemoglobin dropped to $6.7 \mathrm{~g} / \mathrm{dL}$ with WBC count of $5,600 / \mathrm{mm}^{3}$, platelet counts of $1,80,000 / \mathrm{mm}^{3}$ and serum creatinine was $1.5 \mathrm{mg} / \mathrm{dL}$. The patient was admitted and received four units of packed red cells transfusion. The upper GI endoscopy done was normal, stool was negative for occult blood and serum iron profile was within normal limits. Red cell indices were within normal levels. Bone marrow examination reported as pure red cell aplasia probably due to mycophenolatemofetil. Mycophenolate was then replaced by oral azathioprine $100 \mathrm{mg}$ per day and he continued to receive erythropoietin.

After a month of first admission patients hemoglobin dropped to $5.4 \mathrm{~g} / \mathrm{dL}$ and serum creatinine was $1.5 \mathrm{mg} /$ $\mathrm{dL}$. He was re-admitted and 5 units of packed red cells were transfused. Repeat bone marrow examination was done. The bone marrow revealed marked erythroid maturation arrest with large erythroblasts showing blebs protrusions and extrusion of the cytoplasm. (Fig 1, Fig 2)

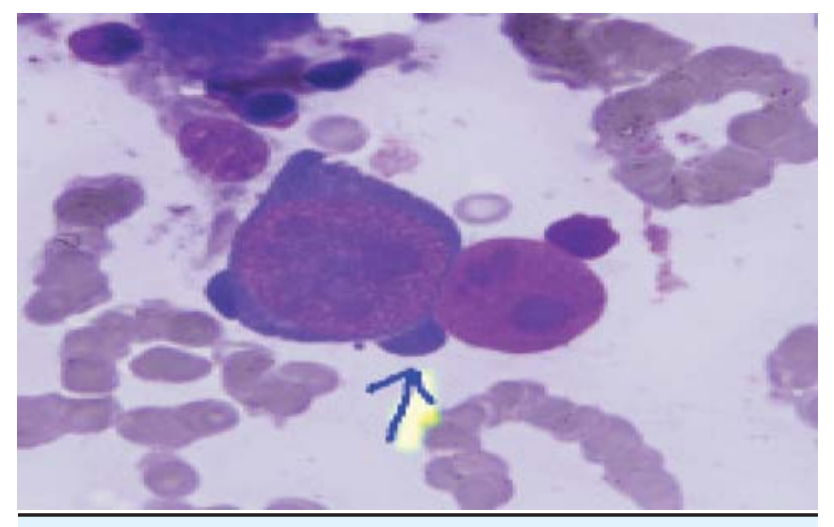

Figure 1. Bone marrow smear showing two giant proeythroblasts. One intact with intranuclear eosinophilic inclusion body like nucleoli. Arrow points to 'dog ear' cytoplasmic projections. Adjacent is a denuded nucleus of a giant proerythroblast

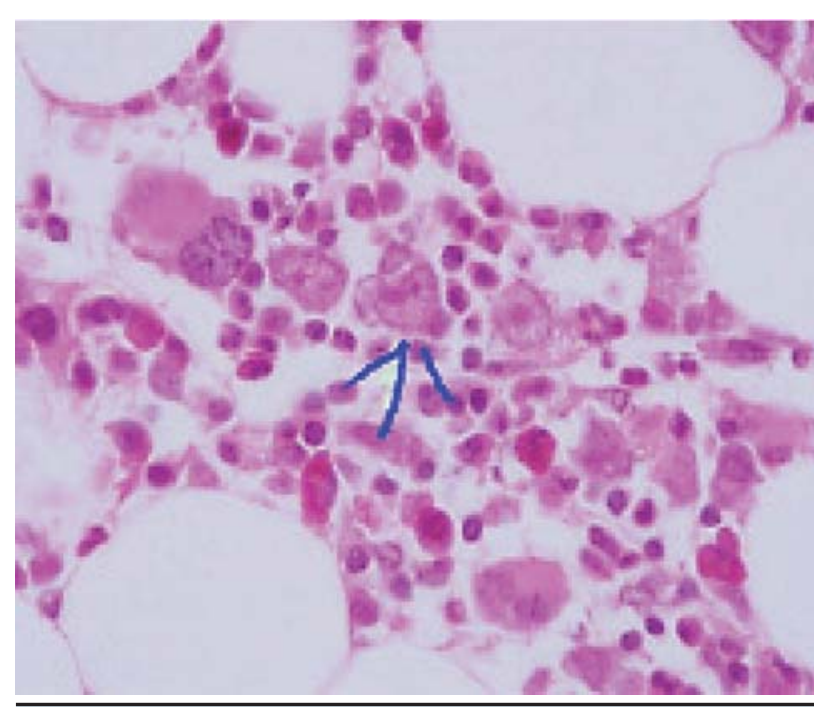

Figure 2. Trephine biopsyshowing giantproerythroblasts with a megakaryocyte at the left hand end of the row

Blood PCR for Parvo B19 virus was sent and serum was tested for the presence of IgM antibodies against Parvo B19 virus both tests were reported as positive.

The patient was admitted and treated with two doses of intravenous immunoglobulin (IVIG) $1.5 \mathrm{~g} / \mathrm{kg}$ per dose. He responded well to treatment and is transfusion free and is off erythropoietin therapy and his hemoglobin at three months post treatment was $12.9 \mathrm{~g} / \mathrm{dL}$ and serum creatinine $1.4 \mathrm{mg} / \mathrm{dL}$. At four months post treatment his serum PCR for Parvo B19 virus is still positive but his hemoglobin was $13.8 \mathrm{~g} / \mathrm{dL}$ and serum creatinine fell to $1.1 \mathrm{mg} / \mathrm{dL}$. His current medications include tacrolimus $2 \mathrm{mg}$ twice daily, azathioprine $50 \mathrm{mg}$ once daily, prednisolone $5 \mathrm{mg}$ once daily and amlodipine 5 mg once daily.

\section{DISCUSSION}

In immunocompetent persons without any underlying hematological problems, Parvovirus B19 infections cause a 5-10 day erythropoietic aplasia, but does not cause significant anemia as their red cell life span is about 120 days. ${ }^{3}$ However, in patients with hemolytic anemias whose red cell life spans are shortened, for example 15 days in hereditary spherocytosis, a transient decompensated erythropoiesis leads to a severe anaemia. ${ }^{3}$ In immunocompromised patients, such as our patient, the infection can persist leading to chronic anemia. Congenital immunodeficient states, human immunodeficiency virus (HIV) infections, post organ transplants, lymphoproliferative disorders are some of the other known immunodeficient states associated with PRCA caused by Parvo virus B19.

As cultures are difficult, the diagnosis rests on the presence of a persistent anaemia, other blood cell counts 
being normal, reticulocytopenia, giant proerythroblasts on bone marrow examination, presence of serum antiParvovirallgM/lgG and PCR for Parvoviral DNA. ${ }^{3}$

Standard treatment for this disease is transfusion of IVIG to enrich the humoral immunity of the patient supported with packed red blood cell transfusions. In the immune competent host, $0.4 \mathrm{~g} / \mathrm{kg} /$ day of IVIG is given for 3 days. In the immunocompromised host, higher doses are required. Because of the cost issues we treated our patient with just two doses of $1.5 \mathrm{~g} / \mathrm{kg}$ per dose which has been tried successfully in other reported cases as well and also higher doses are associated with increase in serum creatinine. ${ }^{8}$ Patients generally respond after two weeks of treatment. Some patients may require more than one course of immunoglobulin therapy and some may benefit from alteration of their immunosuppressive therapy. ${ }^{9-11}$

Other immunomodulatory approaches such as rituximab, steroids, cyclophosphamide, and methotrexate have also been used in chronic PRCA. This is especially the case if it present as the primary haematological disorder, with no obvious cause, or in association with other disease such as lymphorproliferative disorders, connective tissue diseases, thymoma, solid tumors, pregnancy, or following bone marrow transplantation, but rarely in patients with Parvovirus B19 infection. ${ }^{11}$

The first report of Parvovirus B19 infection in a kidney transplant recipient was published in 1986. ${ }^{12}$ Since then, numerous cases of B19 infection after solidorgan transplantations have been reported. However, the clinical burden and true overall impact of B19 infection in the renal transplant population is not well characterized. Wong TY et al demonstrated efficacy of replacing tacrolimus to cyclosporine in a patient who had failed to clear the virus with IVIG treatment. ${ }^{13}$

Pure red cell aplasia can also occur secondary to the use of EPO therapy. ${ }^{14}$ As the patient was on erythropoietin therapy even prior to kidney transplant and his hemoglobin was above the target during that period, we did not test for anti EPO antibodies. This may be the pitfall of our case presentation.

In conclusion, we have reported the first case of PRCA due to Parvo B19 infection in a kidney transplant recipient in Nepal. Since Parvo B19 infection is a rare but possible cause of anemia unresponsive to EPO in immunosuppressed transplanted patients, it should be looked for. We underline the importance of a diagnostic screening using the PCR-PVB19 test and bone marrow cytology, and the rapid response to IVIG therapy. 


\section{REFERENCES}

1. Brown KE, Anderson SM, Young NS. Erythrocyte $\mathrm{P}$ antigen: Cellular receptor for B10 parvo virus. Science.1993; 262:114-17.

2. Hayes-Lattin B, Seipei J, Gatter K, Heinrich MC, Mariarz T. Pure red cell aplasia associated with parvovirus B19 infection occurring late after allogeneic bone marrow transplantation. American J Hematol.2004; 75:142-5.

3. Fisch $\mathrm{P}$, Handgretinger R, Schaefer HE. Pure red cell aplasia.Br J Haematol. 2000;111:1010-22.

4. Forea AV, Lonescu DN, Melhem MF. Parvovirus B19 infection in the immunocompromised host. Arch Pathol Lab Med. 2007;131:799-804.

5. Heegaard ED, Brown KE. Human parvovirus B19. ClinMicrobiol Rev. 2002;15:485-505.

6. Kurukulasuriya A, Hamed AA, MuslahiMA,Ibrahim A. Acquired pure red cell aplasia caused by parvo B19 infection following a renal transplant. SQU Med J.2011,11; 280-3.

7. Waldman M, Kopp JB. Parvovirus B 19 and the kidney.CJASN 2007 ; 2 : S47-S56

8. Liang TB, Li DL, Yu J, BaiXL,Liang L, Xu SG et al. Pure red cell aplasia due to Parvovirus B19 infection after liver transplantation: A case report and review of literature. World J Gastroenterol 2007; 13(13):2007-2010.
9. Waldman M, Kopp JB. Parvovirus-B19-associated complications in renal transplant recipients. Nat ClinPractNephrol. 2007;3:540-50.

10. Choi SH, Chang SP, Won JC, Lee JS, Chi HS, Yang WS et al. A case of persistent anemia in a renal transplant recipient: Association with parvovirus B19 infection. J Infect Dis. 2002;34:71-5.

11. Geetha D, Zachary JB, BaldadoHM ,Kronz JD, Kraus ES. Pure red cell aplasia caused by Parvovirus B19 infection in solid organ transplant recipients: A case report and review of literature. Clin Transplant. 2000; 14:586-91.

12. Neild G, Anderson M, Hawes S, Colvin BT. Parvovirus infection after renal transplant. Lancet 1986;2:12261227.

13. Wong TY, Chan PK, Leung CB, Szeto CC, Tam JS, Li PK .Parvovirus B19 infection causing red cell aplasia in renal transplantation on tacrolimus. Am J Kidney Dis. 1999;34:1132-6.

14. Shinohara K, Mitani N, Miyazaki M, Sakuragi S, Matsuda K, Ogawara S et al. Pure red-cell aplasia caused by the antibody to recombinant erythropoietin, epoetin-beta, in a Japanese patient with chronic renal failure. Am J Hematol. 2005;78,1:15-20. 